Muğla Sıtkı Koçman University, muhammet@mu.edu.tr, Muğla-Turkey

$$
\text { http://dx.doi.org/10.12739/NWSA.2015.10.2.1C0638 }
$$

\title{
SOSYAL BİLGİLER ÖĞRETİMİNDE TARTIŞMALI KONULARLA İLGİLI BİR EYLEM ARAŞTIRMASI
}

\section{ÖZET}

Bu çalışma Sosyal Bilgiler öğretmenlerinin tartışmalı konulardaki öğretim becerilerini geliştirmeyi amaçlayan bir eylem araştırmasıdır. Çalışmanın problemini; sosyal bilgiler öğretmenlerine lisans eğitimleri sırasında tartışmalı konuların sınıflarda nasıl ele alınacă̆ı ile ilgili doğrudan bir eğitimin verilmemesi nedeniyle sosyal bilgiler öğretmenlerin bu konuları sınıflarına getirmekten kaçınmaları oluşturmaktadır. Çalışma sosyal bilgiler öğretmenlerinin bu konuda bilgi ve yeterliliklerini artırmayı amaçlamaktadır. Bu amaçla sosyal bilgiler öğretmenlerine 6 gün süren bir eğitim verilmiştir. Veriler katılımcılara öntest ve sontest uygulanmasıyla toplanmıştır. Toplanan veriler hem yüzde ve frekans olarak rapor edilmiş hem de öntest ve sontest skorları arasında istatistiksel olarak anlamlı bir fark olup olmadığının belirlenmesi için wilcoxon testi ile analiz edilmiştir. Sonuçlar öğretmenlerin tartışmalı konuların sosyal bilgiler derslerinde kullanımı ile ilgili önemli kazanımlar sağladıklarını göstermektedir.

Anahtar Kelimeler: Sosyal Bilgiler Öğretimi, Sosyal Bilgiler Öğretmenleri, Tartışmalı Konular, Öğretim Yöntemleri, Tartışma Teknikleri

\section{AN ACTION RESEARCH REGARDING CONTROVERSIAL ISSUES IN SOCIAL STUDIES INSTRUCTION}

\section{ABSTRACT}

This study is an action research which aims to improve teaching skills of social studies teacher with regard to controversial issues. 24 Social studies teachers across the country participated in the study. The Problem of the study was that social studies teachers do not receive a direct training education regarding instruction in controversial issues during their undergraduate education resulting in refraining from these issues in their classrooms. Thus this study aims to increase knowledge and competencies of social studies teachers regarding this matter. For this purpose a 6-day training has been provided to social studies teachers. The data has been collected through implementation of a pretest and a posttest. The collected data reported as frequencies and percentages in addition to an analysis via paired samples t test to see whether or not statistically significant differences exist between pretest and posttest scores. The results indicate that social studies teachers made important acquisitions regarding the use of controversial issues in social studies course.

Keywords: Social Studies Education, Social Studies Teachers, Controversial Issues, Teaching Methods, Discussion Techniques 


\section{GIRISS (INTRODUCTION)}

Tartışmalı konular; değer veya inanç tartışmalarını içeren, çok sayıda insan tarafından önemli bulunan, toplumun genelini ilgilendiren, evrensel olarak kabul edilmiş sabit bir görüşün olmadığı konulardır. Tartışmalı konuları, sosyal bilgiler sınıflarında ele alınan diğer konulardan ayıran bazı özellikler vardır. Berg, Graffe ve Holden'e (2003) göre bir tartışmalı konuda genellikle değerler çatışması söz konusudur. Çatışan değerler duyguları güçlü bir şekilde harekete geçirmiş ve konu politik bir duyarlılık kazanmıştır. Konular hem zamanla çok sayıda bileşenin eklenmesi hem de farklı açılardan ele alınabilme özelliklerine bağlı olarak son derece karmaşıklaşmıştır ve güncel bir ilginin objesi durumundadırlar.

\subsection{Neden Tartışmalı Konular? (Why Controversial Issues?)}

Tartışmalı konular eğitimi hem toplum, hem öğretmenler, hem de öğrenciler açısından önemli fırsatları içermektedir. Hiç kuşkusuz toplum açısından en önemli fırsatı demokratik bir toplumda yaşayacak bireylere ihtiyaç duyacakları beceri, tutum ve davranışları kazandırma fırsatıdır. Cogan ve Derricott'a (Akt: Berg, Graffe ve Holden, 2003) göre 21. Yüzyılın demokratik vatandaşları diğer bireylerle işbirliği içerisinde çalışır; kendi eylemlerinde kılavuzluk sağlamak üzere sosyal adalet ilkelerini benimser; eleştirel ve sistemli bir şekilde düşünür; kültürel farklılıkları takdir eder ve bu farklılıklardan bir şeyler öğrenir; sadece yakın değil uzak çevresindeki ve küresel bağlamdaki problemleri değerlendirebilir; problemlerini şiddete başvurmadan çözer; çevreyi koruyabilmek için yaşam tarzında değişiklikler yapar; insan haklarını kabul eder ve savunur; daha adil bir gelecek için çabalar ve demokratik siyasete katılır. Bu özelliklere sahip olarak yetişecek öğrencilere verilecek vatandaşlık eğitiminin özünde üzerinde anlaşma olmayan konuların açık ve demokratik bir şekilde tartışılmasının yer alması kaçınılmazdır.

Öğretmenler açısından bakıldığında tartışmalı konuların yaratacağı merak duygusuyla öğrencileri daha güçlü bir şekilde güdülemek ve etkili öğrenim deneyimleri yaşatmak mümkün olacaktır (Strauss ve Westlund, 2005). Öğrencileri güdüleyebilmenin öğretmenler açısından ne kadar önemli ve zor olduğu göz önüne alınırsa bunun çok önemli fırsat olduğu daha iyi anlaşılacaktır. Öğrenciler açısından ele alındığında ise tartışmalı konuları sosyal bilgiler derslerine taşımanın ilk yararı öğrencilerin ailelerinden, medyadan veya diğer kaynaklardan bu konuları duymaları ve bu konular hakkında sahip olmak istedikleri bilgilere ulaşma fırsatı sağlamasıdır. Bu konuların sınıflarda ele alınmaması, okulların öğrencileri düşünmeye, yansıtmaya, analiz etmeye ve değerlendirmeye yöneltici eğitici niteliklerinden uzaklaşması; kalıplaşmış yaklaşımların benimsetilmeye çalışıldığı kurumlara dönüşmesi demektir (Woolley, 2010).

Öğrencilerin kendi düşüncelerini geliştirip ifade ederken diğerlerinin düşüncelerini de dinleyip anlamaya çalışabilecekleri fırsatlara ihtiyaçları vardır. Sınıfın güvenli ortamı öğrencilerin bu becerileri geliştirebilecekleri en iyi ortamlardan birisidir (Wooley, 2010). Strauss ve Westlund'a (2005) göre bu konuların ele alınması sırasında öğrencilerin çeşitıi bakış açılarına maruz kalmaları onların sosyal, ahlaki, manevi kültürel tutum ve becerilerinin gelişmesine fırsat verecektir. Farklı bakış açılarına maruz kalmanın diğer bir faydası da hem yerel hem de ulusal veya küresel ölçekte bir arada yaşama ve uzlaşı kültürünün (Asimeng-Boahene, 2007) ve empati becerisinin gelişmesi (Advisory Group on Citizenship, 1998; Strauss ve Westlund, 2005) olacaktır. 
Ayrıca karmaşık konuların küçük detaylara ayrılarak incelenmesi onların politik okuryazarlığını artıracak ve toplumsal konulara etkin olarak katılmaya teşvik edecektir (Strauss ve Westlund, 2005). Tartışmalı konular öğretimi ile öğrencilerin gelecekte politik hayata katılımları arasında pozitif bir ilişki bulunmaktadır (Barton ve McCully, 2007; Strauss ve Westlund, 2005). Çünkü tartışmalı konular eğitimi alan öğrenciler karar alma süreçlerine katılmaya istekli olurlar; özgürlüğün kıymetini bilirler; alternatifler arasında seçim yapmayı öğrenirler ve karar verirken adil olmanın önemini kavrarlar (Advisory Group on Citizenship, 1998).

Öğrenciler ayrıca günümüz dünyasında yaşayabilmek için hayati önemi haiz becerileri kazanırlar (Advisory Group on Citizenship, 1998; Strauss ve Westlund, 2005; Wooley, 2010). Bu becerileri Pakistan Higher Education Comission (2012:18) bilgi işleme becerileri, mantık becerileri, sorgulama becerileri, yaratıcı düşünme becerileri ve değerlendirme becerileri olarak sınıflamış ve detaylandırmıştır.

\section{2. ÇALIŞMANIN ÖNEMI (RESEARCH SIGNIFICANCE)}

Tartışmalı konular bireysel veya toplumsal olarak hassas olan konuları içerdiğinden sınıfta ele alınması da özel bir dikkati gerektiren konulardır. Tartışmalı konularla öğretiminde yaşanan güçlükler Yazıcı ve Seçgin (2010) tarafından: "eğitimin sınav odaklı olması, yanlış anlaşılma korkusu, okul idaresinin tepkisi, öğretmenin tartışılan konuda yetersizliği, öğrencilerin tartışmayı gereğinden fazla abartması, öğrencilerin hazır bulunuşluk düzeyi, bulunulan yerin örf ve adetleri, soruşturma açılması korkusu, öğrenci velilerinin tepkisi, öğrencilerin tepkisi, programın yoğunluğu, öğrencileri yanlış yönlendirme korkusu, öğrencilerin tartışmayı sınıf dışına taşıma ihtimali, tartışmayı yönetememek" (s.408) olarak belirtilmiştir. Asimeng-Boahene (2007) sınıflarda tartışmalı konuları öğretmenin, öğrencileri yararlı tartışmalara yöneltmenin bir sanat olduğunu ve bir takım becerileri gerektirdiğini ve uygulamalar yapılmasına ihtiyaç duyulduğunu belirtmekte ve tartışmalı konular öğretiminde deneyimli öğretmen eksiğinin en büyük sıkıntılardan birisi olduğunu savunmaktadır. Öğretmenler tartışma konusunun nasıl seçilmesi gerektiği; öğrencilerin tartışmaya nasıl hazırlanacağı; sınıfa getirilecek bilgi kaynakları; tartışmanın rahatlıkla yapılacağı bir sınıf atmosferinin nasıl oluşturulacağı; tartışmanın odağının ve yönünün nasıl muhafaza edileceği; tartışmanın dengeli olarak nasıl yürütüleceği; öğrencilerin eşit katılımının nasıl sağlanacağı ve kendi görüşünü açıklayıp açıklamamsı gerektiği ve eğer açıklanacaksa bunun nasıl olması gerektiği konusunda yeterli bilgi ve beceriye sahip olmalıdır (Harwood and Hahn, 1990). Tartışmalı konular öğretiminde öğretmenlerin üzerine düşen birçok sorumluluk vardır. Öğretim planlanması, öğrencilerin kültürel arka planlarının ve hazır bulunuşluklarının belirlenmesi, güvene dayalı pozitif bir sınıf ortamının yaratılması, öğrencilerde tartışma beceri ve tutumlarının geliştirilmesi, eleştirel düşüncenin teşvik edilmesi, öğrenci direnci saygı gösterilmesi ama bu direncin aşılması, öğretilebilir anlardan yararlanılması, duygusallıkla baş edilmesi, uygunsuz davranışların önlenmesi ve ortadan kaldırılması gibi sorumluluklar öğretmeni beklemektedir (University of Western Australia).

Bu güçlüklerin çok önemli bir bölümü öğretmenlerin yeterli bilgi ve beceriye sahip olmalarıyla çözümlenebilecek konulardır. Tartışmalı konuların öğretimin en önemli unsuru öğretmenlerin bu tartışmaları sınıfında gerçekleştirmek için gerekli eğitime sahip olmasıdır. Ülkemizde ise tartışmalı konuların nasıl öğretilebileceği ilgili sosyal bilgiler öğretmen adaylarının alabileceği lisans seviyesinde bir ders bulunmamaktadır. Dolayısıyla sosyal bilgiler öğretmenlerinin 
öğretmenlerin karşılaştıkları formal eğitim eksikliği kaynaklı problemlere bir çözüm üretebilmek için böyle bir eylem araştırmasına gerek duyulmuştur.

Bu bağlamda bu çalışma ile sosyal bilgiler öğretmenlerine tartışmalı konular kavramı ve tartışmalı konular öğretimi sırasında karşılaşabilecekleri güçlükler hakkında teorik bilgi sağlamak ve çözüm önerilerinde bulunarak; tartışmalı konulara uygun sınıf ortamının nasıl yaratılabileceği ve sınıf yönetimi hakkında bilgi aktarmak ve en önemlisi sınıflarında uygulayabilecekleri çeşitli öğretim yöntemlerini tanıtmak amaçlanmaktadır. Çalışmanın önemi temel olarak eğitim uygulamalarına yapacağı katkıdan ileri gelmektedir. Tartışmalı konuların sosyal bilgiler öğretmenleri tarafından daha bilinçli ve hazırlıklı olarak sınıfa getirilmesi yukarıda gösterilen yararları sağlamasının yanında sosyal bilgiler öğretim programında gösterilen ders amaçları olan öğrencilerin eleştirel düşünme, problem çözme, yaratıcı düşünme ve nihai olarak karar verme becerilerinin geliştirilmesine de katkı sağlayacaktır.

\section{YÖNTEM (METHOD)}

Çalışma bir Eylem araştırması olarak gerçekleştirilmiştir. Fraenkel, Wallen ve Hyun'a (2012) göre eylem araştırması eğitim ile ilgili uygulamaları geliştirebilmek için bir problemi çözmek veya bir konu ile ilgili bilgi toplamak için bir veya daha fazla kişi tarafından gerçekleştirilen araştırmalardır. Eylem araştırması yapan araştırmacılar genellikle gerçek bir problemi çözme amacını taşırlar. $\mathrm{Bu}$ çalışma araştırmacının bir eğitim fakültesinin sosyal bilgiler anabilim dalında görevli olması sebebiyle sık sık bir araya geldiği sosyal bilgiler öğretmenlerinin tartışmalı konuların öğretimiyle ilgili problem yaşadıklarını gözlemlemesiyle, bu sorunu çözmek için planlanmıştır. Çalışmada eylem araştırması yöntemlerinden pratik eylem araştırması yöntemi (Fraenkel, Wallen ve Hyun, 2012) kullanılmıştır.

\section{1. Çalışmanın Katılımcıları (Participants)}

Çalışmaya katılım Türkiye'de görev yapan bütün sosyal bilgiler öğretmenlerine açık tutulmuştur. Ancak maddi şartların elverişli olmaması sebebiyle başvurular arasında bir seçim yapmak gerekmiştir. Seçim kriterleri olarak Cinsiyet, görev yapılan il ve kıdem belirlenmiştir. Öncelikle katılımcıların cinsiyet sayıları bakımından birbirlerine eşit olmalarına çalışılmıştır. Daha sonra İstanbul ve Ankara için 2'şer diğer iller için de 1'er kişilik kontenjanlar belirlenmiştir. Son olarak ise kıdeme göre seçim yapılması benimsenmiştir. Böylelikle katılımcıların mümkün olduğunca farklı yerlerden olması, dolayısıyla da yaygın etkin artırılması hedeflenmiştir. Sonuç olarak çalışmaya ülkenin çeşitli illerinden 24 sosyal bilgiler öğretmeni katılmıştır. 1 sosyal bilgiler öğretmeni ise kabul edildiği halde çalışmaya katılmamıştır.

\subsection{Verilerin Toplanması (Data Collection)}

Veriler araştırmacı tarafından Guyton ve Hoffman'ın Tartışmalı Konular Öğretim Anketinden (Akt: Byford, Lennon ve Russell, 2009) de yararlanarak oluşturulan bir veri toplama aracı ile toplanmıştır. Söz konusu veri toplama aracının geçerliğini sağlamak için her bir maddeye ilişkin olarak üç sosyal bilgiler alanında uzmanından görüş alınmıştır. Uzmanlardan her bir maddeyi 1 ve 5 aralığında değerlendirmeleri istenmiştir. Ortalama olarak 4'ün altında değerlendirilen maddeler çıkarılmış veya yeniden yazılarak uzman görüşüne sunulmuş ve ankete son şekli verilmiştir. Söz konusu anket ilk olarak projenin ilk günü tanışma toplantısından hemen sonra uygulanmıştır. 6 günlük eğitim sonrasında ölçek bir daha uygulanarak 
veriler elde edilmiştir. Ölçeğin güvenirliği Cronbach's Alpha= ,62 olarak belirlenmiştir. Güvenirlik skoru görece düşük olmakla beraber kabul edilebilirlik sınırları içerisindedir. Öte yandan eylem araştırmalarının dış geçerliği (genellenebilirliği) son derece kısıtlı olduğundan (Fraenkel, Wallen and Hyun, 2012) nicel araştırmalarda olduğu gibi güvenirlik ve nesnellik yansıtılmaz (Kuzu, 2009).

\subsection{Verilerin Analizi (Analysis of The Data)}

Toplanan veriler SPSS istatistiksel analiz yazılımı aracılığı ile analiz edilmiştir. Veriler anketteki her bir madde için öntest ve sontest ortalama değerleri olarak rapor edilmiştir. Daha sonra ise ortalamalar arasinda istatistiksel olarak anlamlı bir fark olup olmadığını anlamak için wilcoxon testi uygulanmış ve sonuçlar tablo halinde rapor edilmiştir. Wilcoxon testinin tercih edilmesinin sebebi katılımcı sayısının parametrik analizler için yeterli olmamasıdır.

\subsection{Eylem Planı (Action Plan)}

Çalışma 6 iş günü olarak planlanmıştır. Çalışmanın birinci gününde tartışmalı konularla ilgili teorik bilgilere, uygulamada karşılaşılan zorluklara ve olası çözüm yollarına değinilmiştir. Bu kapsamda ilk olarak tartışmalı konular kavramı hangi konuların tartışmalı olduğu ele alınmıştır. Daha sonra tartışmalı konuların öğretimi sırasında karşılaşılan güçlüklere değinilmiştir. Son olarak da tartışmalı konuların öğretimi sırasında öğretmenlerin dikkate alması gereken hususlar hakkında teorik bilgilendirme yapılmıştır. Çalışmanın takip eden 4 gününde sosyal bilgiler öğretmenlerinin sınıflarında ele alabilecekleri 4 öğretim yöntemi tanıtılmıştır. Her bir yöntem için bir çalışma günü ayrılmış, bu günlerde 3'er örnek ders sunulmuş ve gün sonunda katılımcılardan söz konusu öğretim yöntemine uygun bir ders planı tasarlamaları istenmiştir. Çalışmanın 6 . ve son gününde ise katılımcılar hazırlamış oldukları ders planları arasından bir ders planı seçerek uygulamışlardır.

\section{5. Çalışmada Ele Alınan Öğretim Yöntemleri (Instruction Methods Presented in the Study)}

Çalışmada ele alınan öğretim yöntemleri aşă̆ıda sunulmuştur.

- Yöntem 1. Puanlandırılmış tartışma: Rossi (2006) tarafından belirtilen tekniğe göre bir puanlandırılmış tartışma 3'ten 8'e kadar değişen sayılarda öğrenciden oluşan bir grup öğrenci arasındaki iletişimdir. Konuşmalar öğrencilerin öncülüğünde gerçekleşir, açık uçlu sorular temelinde yürütülür ve tartışma sırasında öğretmen herhangi bir müdahalede bulunmaz. Grubun amacı bir tartışmalı konu hakkında bir uzlaşıya varmaya çalışmaktır. Öğretmen önceden belirlenmiş bir puanlama sistemi çerçevesinde mental süreçleri ve pozitif ve negatif davranışları göz önünde bulundurarak değerlendirme yapar. Bir puanlandırılmış tartışmanın hazırlanması ve yapılması altı adımdan oluşmaktadır.

- Tartışmalı konunun geliştirilmesi

- Tartışma süreçlerinin açıklanması

- Konunun araştırılması

- Konun tartışılmasi

- Tartişmanin sorgulanmasi

- Tartışmanın değerlendirilmesi

Puanlandırılmış tartışmanın en güçlü yanlarından birisi bu yöntemin öğrencilere tartışma kurallarını öğretmesidir. öğrencilerin çoğu, yetişkinler arasındaki tartışmaların informal kurallarını çok az bilmektedir. Öğrencilerin medyada rastladıkları örneklerin çoğu bu kurallara uymamaktadır. Ayrıca 
puanlama sistemi en sessiz öğrenciler için bile grubunun desteğine güvenerek tartışmalara katılması için bir özendirme unsuru olmaktadır. Üçüncü güçlü yanı ise her gruba kendi tartışmasını tasarlama, uyarlama ve değerlendirme özerkliği sağlamasıdır. Sonuç olarak bu güçlü yönleriyle, puanlandırılmış tartışma demokratik diyalog için gerekli becerileri ve tutumları geliştirme potansiyeline sahiptir.

- Yöntem 2. Yapılandırılmış akademik tartışma: Johnson ve Johnson (1988) tarafından geliştirilen Yapılandırılmış Akademik Tartışma, tartışmalı konuların uzlaşmaya ulaşması modeline göre geliştirilmiş bir tartışma yöntemidir. Bu yöntemin gerekçesi "tartışmalar, kazan - kaybet durumları değil, çözülmesi gereken ilginç konular olarak tanımlanmalıdır". Bu yöntemin amacı öğrencilerin tartışılan konu ile ilgili farklı bakış açılarını inceledikten sonra, bir işbirliği ortamında uzlaşma kararlarına varmalarını sağlamaktır. Yöntemin aşamaları aşağıdaki gibidir.

- Tartişma konusun tanımlanmasi

- Gruplarin oluşturulmasi

- Farklı görüşlerin araştırılması

- Görüşlerin sunulmasi

- Görüşlerin tersyüz edilmesi

- Bir karara varılması

- Tartışmanin sorgulanma süreci.

Yapılandırılmış Akademik Tartışma tekniğinin güçlü yanları farklı görüş açıları ve çatışma yönetim becerileri üzerine odaklanmış olmasıdır. Bu etkinlikte öğrenciler bir bakış açısını benimseme ve savunma becerilerini uygularlar, daha sonra karşıt görüşleri inceleyerek kendi bakış açılarını genişletirler. Öğrencilerin bakış açısı benimseme becerileri gelişir. Ayrıca etkinlik öğrencilerin, konuyu hatırlama, daha nitelikli kararlar verme ve problem çözmeye daha yüksek bir duygusal bağlılık gösterirler. Etkinlik öğretmenler ve öğrencilere tartışmalı konuları olumlu vatandaşlık kazanımları üretecek şekilde başlatma ve yönetme modeli sağlar.

- Yöntem 3. Savunmacı karar verme: Rossi (2006) tarafından sunulan Savunmacı Karar Vermenin amacı öğrencilerin her birinin güncel veya tarihi bir kamusal tartışma konusu ile ilgili bir görüşü benimsedikleri ve savundukları anlamlı tartışmalar yapmalarını sağlamaktır. Yapılandırılmış Akademik Tartışmanın tersine bu bir münakaşadır ama formel ve klasik modeller takip edilmez. Bu bir savunucu, karar verici, öğrenci öncülüğünde küçük grup etkinliğidir ancak bütün öğrencilerin bir rolü vardır ve bireysel katılımı da en üst seviyeye çıkarır. Bu teknik tartışmalı konuların sınıfta tartışılmasının aydınıık kadar ateş de gerektirdiği kabulüne dayanır. Münakaşanın yarışma odaklı olması motivasyonu, ilgiyi ve tutkuyu artırarak düşünme gücünü ateşler. Bununla beraber Savunucu Karar Verme, medeni bir tartışma kurallarını ve kanıtlara dayalı iddialarda bulunulmasını da teşvik eder. Model altı adımdan oluşmaktadır

- Sahnenin kurulmasi

- Rollerin seçilmesi

- Konunun araştırılması

- Konunun tartışılması

- Tartişmanın sorgulanmasi

- Etkinliğin değerlendirilmesi

Savunucu Karar Verme yönteminin gücü bütün öğrencileri aktif olarak tartışmaya dâhil etmesinden ileri gelmektedir. 
Genellikle, sadece sözel becerisi yüksek birkaç öğrencinin katıldığı diğer sınıf tartışmalarının aksine savunucu Karar Verme'de her öğrenci ya savunucu ya da karar verici olarak etkinliğe katılır ve bireysel bir katkı sağlar. Küçük gruplardaki tartışma formatı bir rekabet yaratır ve öğrencileri motive eder. Tartışma başlamadan önceki hazırlık aşaması tartışmaların doyurucu bir şekilde yapılmasını sağlar. Ayrıca bu yöntem öğrencilerin derse kendilerini daha fazla verdikleri ve daha yüksek düşünme becerileri kullandıkları bir sınıf atmosferi yaratır ki bu da tartışmalı konular dâhil birçok konunun ele alınabilmesi açısından yararlar sağlar.

- Yöntem 4. Aydınlanan sırlar: Clarke (2009) tarafından geliştirilen yöntem dört adımdan oluşmaktadır:

- Tartışma Konusu ne hakkında? Tartışmalı konuyla ilgili olarak bilinmesi gereken şeylerden birincisi tartışılan konunun ne olduğunun göründüğü kadar açık veya basit olmayabileceği gerçeğidir. Buradaki önemli nokta üzerinde tartışma yapılan anahtar sorunun ne olduğunu belirlemektir. Hemen hemen her çatışma üç tip soru etrafında meydana gelir: Değerlerle ilgili çatışmalar ( Ne olmalı? Hangisi daha iyi?), bilgiyle ilgili çatışmalar (gerçek nedir? Olay nedir?) ve kavramlarla ilgili çatışmalar (bunun anlamı ne? Bu nasıl tanımlanmalı?). Kısaca buradaki tartışma ne hakkında: değerler mi, bilgi mi yoksa kavramlar mı? Böylece öğrencilere serinkanlı bir analiz yapma firsatı da verilmiş olur.

- İddialar nelerdir? Öğrenciler tartışmanın ne hakkında olduğunu ve çatışmanın özünü belirledikten sonra ikinci aşamada konuyla ilgili çeşitli görüşleri desteklemek için ileri sürülen iddiaların analizi yapılır. Buradaki en büyük sorun konuyla ilgili nelerin söylendiği ve iddiaların arkasında yeterli desteğin olup olmadığını belirlemektir. Bu adım iddiaların içeriğinin belirlenmesini gerektirdiğinden büyük ölçüde analitik bir adımdır. Aynı zamanda bir dereceye kadar da yargılayıcıdır. Öğrenciler bu adımda bir tartışmalı konuyla ilgili bir görüşün geçerliğini yargılamaya başlarlar.

- Varsayılanlar neler? Öğrenciler bir konuyla ilgili görüşleri inceledikten sonraki aşamada kritik soru şudur: varsayımlar veya tartışmasız kabul gördüğü düşünülen iddialar nelerdir. Bu aşama bir görüşün geçerliğini belirlemek için ilkelerden yararlanıldığı aşamadır. Bu sürecin kalbinde değerlerin göreceliği anlayışını bir kenara bırakmak yatar. Herhangi bir görüşün en az diğeri kadar kabul edilebilir veya meşru olduğu doğru değildir. Eğer bir görüşü haklı çıkarmak için öne sürülen varsayımlar önyargılara dayalıysa, eğer iddiaların arakasındaki tutumlar etnosentrik, ırkçı veya mezhepsel ise, - zaman bu varsayımlar eleştiriye açıktır ve iddianın meşruluğu azalır.

- İddialar nasıl manipüle edilmiştir? Bu adım yöntemde, tartışıan konunun siyaseti ile ilgili soruların sorulduğu adımdır. Bu adım öğrenciler açısından özellikle önemlidir çünkü bu adım bilginin görüşleri etkilemek için nasıl kullanıldığını anlamalarına yardım eder. Bir iddianın nasıl manipüle edildiğini anlamaları için öğrencilerin ilk olarak kimlerin konuya müdahil olduğunu ve onların konuyla ilgili özel ilgilerinin, çıkarlarının ne olduğunu belirlemeleri gerekir. 


\section{BULGULAR (FINDINGS)}

Çalışma kapsamında sosyal bilgiler öğretmenlerine uygulamış olan öntest ve sontest sonuçlarına ilişkin bulgular Tablo 1 ve Tablo 2' de sunulmuştur. Tablo $1^{\prime}$ de sunulan ortalamalara göre sosyal bilgiler öğretmenlerinin görüşlerinin 8. İfade dışında bütün ifadeler bakımından istenilen yönde geliştiği anlaşılmaktadır. 8. Ifadede ise herhangi bir değişiklik yaşanmamıştır.

Tablo 1. Tartışmalı konularla ilgili öğretmen görüşlerine ilişkin öntest ve sontest ortalamaları

(Table 1. Mean scores of pretest and posttest results regarding teacher views about controversial issues)

\begin{tabular}{|c|c|c|c|c|c|}
\hline & \multicolumn{2}{|l|}{ İfadeler } & $X$ & $\mathrm{~N}$ & SD \\
\hline \multirow{2}{*}{1} & \multirow{2}{*}{$\begin{array}{l}\text { Hiçbir konu otomatik olarak sosyal bilgiler } \\
\text { sınıflarının dışında tutulmamalıdır }\end{array}$} & ö1 & 4,30 & 23 & 0,92 \\
\hline & & s1 & 4,56 & 23 & 0,72 \\
\hline \multirow{2}{*}{2} & \multirow{2}{*}{$\begin{array}{l}\text { Öğrenciler tartışmalı konular öğretimine gerek } \\
\text { duyarlar }\end{array}$} & 2 & 4,60 & 23 & 0,58 \\
\hline & & $\mathrm{s} 2$ & 4,82 & 23 & 0,38 \\
\hline \multirow{2}{*}{3} & \multirow{2}{*}{$\begin{array}{l}\text { Sosyal bilgiler ders kitaplarında tartışmalı } \\
\text { konulara yeterince yer verilmektedir }\end{array}$} & ö3 & 2,40 & 22 & 1,00 \\
\hline & & s3 & 2,52 & 23 & 1,08 \\
\hline \multirow{2}{*}{4} & \multirow{2}{*}{$\begin{array}{l}\text { Öğrenciler tartışmalar ve çatışmalarla } \\
\text { uğraşmayı gerçekten istemiyorlar. }\end{array}$} & Ö4 & 2,78 & 23 & 0,95 \\
\hline & & s4 & 2,43 & 23 & 1,03 \\
\hline \multirow{2}{*}{5} & \multirow{2}{*}{$\begin{array}{l}\text { Ülkemizin istikrarı vatandaşların en önemli } \\
\text { konularda uzlaşmaya varmalarına bağlıdır. }\end{array}$} & ö5 & 4,08 & 23 & 1,16 \\
\hline & & s5 & 4,43 & 23 & 0,58 \\
\hline \multirow{2}{*}{6} & \multirow{2}{*}{$\begin{array}{l}\text { Öğrencilere çatışmalarla ve tartışmalarla } \\
\text { nasıl baş edebileceklerini öğretmek önemlidir }\end{array}$} & 0̈6 & 4,82 & 23 & 0,20 \\
\hline & & s6 & 4,95 & 23 & 0,38 \\
\hline \multirow[b]{2}{*}{7} & \multirow{2}{*}{$\begin{array}{l}\text { Bir kişi bir konu hakkında kesin kararlara ve } \\
\text { sonuçlara varmak için o konu hakkındaki bütün } \\
\text { görüşleri incelemelidir. }\end{array}$} & Ö7 & 3,69 & 23 & 1,32 \\
\hline & & s 7 & 4,39 & 23 & 0,72 \\
\hline \multirow{2}{*}{8} & \multirow{2}{*}{$\begin{array}{l}\text { Tartışmalı konularla uğraşmak öğrencilerin } \\
\text { kafasını karıştırır ve yılgınlığa yol açar. }\end{array}$} & 0̈8 & 1,69 & 23 & 0,55 \\
\hline & & s8 & 1,69 & 23 & 0,76 \\
\hline \multirow{2}{*}{9} & \multirow{2}{*}{$\begin{array}{l}\text { Tartışmalı konuları öğretmek için kendimi } \\
\text { yeterli hissediyorum }\end{array}$} & 0̈9 & 3,30 & 23 & 0,87 \\
\hline & & s9 & 4.00 & 23 & 0,95 \\
\hline \multirow{2}{*}{10} & \multirow{2}{*}{$\begin{array}{l}\text { Öğretmenler tartışmalı konuları öğretmek için } \\
\text { sistematik bir yöntem geliştirmelidir. }\end{array}$} & ö10 & 4,39 & 23 & 0,58 \\
\hline & & $\mathrm{s} 10$ & 4,65 & 23 & 0,48 \\
\hline \multirow[b]{2}{*}{11} & \multirow{2}{*}{$\begin{array}{l}\text { Öğretmenler kendilerini korumalı ve toplumun } \\
\text { tartışmalı olarak gördüğü bir konuyu } \\
\text { öğretmemelidir. }\end{array}$} & ö11 & 1,86 & 23 & 0,81 \\
\hline & & s11 & 1,82 & 23 & 0,71 \\
\hline \multirow[b]{2}{*}{12} & \multirow{2}{*}{$\begin{array}{l}\text { Eğitim sistemi tartışmalı konuların } \\
\text { öğretilmesini destekleyen resmi bir politika } \\
\text { geliştirmelidir. }\end{array}$} & $\ddot{0} 1$ & 1 & 22 & 0 \\
\hline & & $\mathrm{s} 12$ & 4 & 23 & 0,49 \\
\hline \multirow[b]{2}{*}{13} & \multirow{2}{*}{$\begin{array}{l}\text { Bazen bir konuyla ilgili tartışmaları } \\
\text { görmezden gelmek ve sadece olguları öğretmek } \\
\text { daha iyidir. }\end{array}$} & ö1 & 2,56 & 23 & 1,27 \\
\hline & & s13 & 2,13 & 23 & 0,96 \\
\hline
\end{tabular}

Sosyal bilgiler öğretmenlerinin görüşlerinin öntest ve sontest skorları bakımından anlamlı bir fark gösterip göstermediğine bakmak için wilcoxon testi uygulanmış ve sonuçlar Tablo 2'de sunulmuştur. Buna göre dört ifade bakımından istatistiksel olarak anlamlı değişikliklerin yaşandı ğı gözlenmiştir. 
Tablo 2. Öğretmenlerin öntest ve sontest skorlarına ilişkin wilcoxon testi sonuçları

(Table 2. Wilcoxon test results regarding pretest and posttest scores of the theachers)

\begin{tabular}{|c|c|c|c|c|c|c|}
\hline Ifade No & Sontest-Öntest & $\mathrm{n}$ & Sira Ort. & Sira Top. & $\mathrm{z}$ & $\mathrm{p}$ \\
\hline \multirow{4}{*}{1} & Negatif sıra & 2 & 6,50 & 13,00 & $-1,185 *$ & 0,236 \\
\hline & Pozitif sura & 7 & 4,57 & 32,00 & & \\
\hline & Eşit sıra & 13 & & & & \\
\hline & Toplam & 22 & & & & \\
\hline \multirow{4}{*}{2} & Negatif sıra & 3 & 4,50 & 13,50 & $-1,155^{\star}$ & 0,248 \\
\hline & Pozitif sura & 6 & 5,25 & 31,50 & & \\
\hline & Eşit sıra & 13 & & & & \\
\hline & Toplam & 22 & & & & \\
\hline \multirow{4}{*}{3} & Negatif sıra & 6 & 7,00 & 42,00 & $-0,254 *$ & 0,799 \\
\hline & Pozitif sira & 7 & 7,00 & 49,00 & & \\
\hline & Eşit sıra & 8 & & & & \\
\hline & Toplam & 21 & & & & \\
\hline \multirow{4}{*}{4} & Negatif sıra & 10 & 8,25 & 82,50 & $-1,316 *$ & 0,188 \\
\hline & Pozitif sira & 5 & 7,50 & 37,50 & & \\
\hline & Eşit sıra & 7 & & & & \\
\hline & Toplam & 22 & & & & \\
\hline \multirow{4}{*}{5} & Negatif sıra & 4 & 4,50 & 18,00 & $-1,393 *$ & 0,163 \\
\hline & Pozitif sura & 7 & 6,86 & 48,00 & & \\
\hline & Eşit sıra & 11 & & & & \\
\hline & Toplam & 22 & & & & \\
\hline \multirow{4}{*}{6} & Negatif sıra & 4 & 3,00 & 12,00 & $-1,342 *$ & 0,180 \\
\hline & Pozitif sura & 1 & 3,00 & 3,00 & & \\
\hline & Eşit sıra & 17 & & & & \\
\hline & Toplam & 22 & & & & \\
\hline \multirow{4}{*}{7} & Negatif sıra & 3 & 2,00 & 6,00 & $-2,218 *$ & $0,027 * \star$ \\
\hline & Pozitif sura & 7 & 7,00 & 49,00 & & \\
\hline & Eşit sıra & 12 & & & & \\
\hline & Toplam & 22 & & & & \\
\hline \multirow{4}{*}{8} & Negatif sıra & 4 & 4,00 & 16,00 & $-0,302 *$ & 0,793 \\
\hline & Pozitif sura & 4 & 5,00 & 20,00 & & \\
\hline & Eşit sıra & 14 & & & & \\
\hline & Toplam & 22 & & & & \\
\hline \multirow{4}{*}{9} & Negatif sıra & 1 & 14,00 & 14,00 & $-2,473 *$ & $0,013 * *$ \\
\hline & Pozitif sura & 13 & 7,00 & 91,00 & & \\
\hline & Eşit sıra & 8 & & & & \\
\hline & Toplam & 22 & & & & \\
\hline \multirow{4}{*}{10} & Negatif sıra & 1 & 4,50 & 4,50 & $-2,121 *$ & $0,034 * *$ \\
\hline & Pozitif sura & 7 & 4,50 & 31,50 & & \\
\hline & Eşit sıra & 14 & & & & \\
\hline & Toplam & 22 & & & & \\
\hline \multirow{4}{*}{11} & Negatif sıra & 5 & 6,00 & 30,00 & $-0,302 *$ & 0,763 \\
\hline & Pozitif sira & 6 & 6,00 & 36,00 & & \\
\hline & Eşit sıra & 11 & & & & \\
\hline & Toplam & 22 & & & & \\
\hline \multirow{4}{*}{12} & Negatif sıra & 2 & 4,00 & 8,00 & $-1,811 *$ & 0,070 \\
\hline & Pozitif sura & 7 & 5,29 & 37,00 & & \\
\hline & Eşit sıra & 12 & & & & \\
\hline & Toplam & 21 & & & & \\
\hline \multirow{4}{*}{13} & Negatif sura & 9 & 5,72 & 51,50 & $-2,521 *$ & $0,012 * *$ \\
\hline & Pozitif sura & 1 & 3,50 & 3,50 & & \\
\hline & Eşit sıra & 12 & & & & \\
\hline & Toplam & 22 & & & & \\
\hline
\end{tabular}

*Negatif siralar temeline dayalı

$\star \star P<0.05$ 
Çalışma sonucunda sosyal bilgiler öğretmenlerinin görüşlerinde dört ifade bakımından istatistiksel olarak anlamlı ve çalışmanın hedeflediği yönde değişiklikler meydana gelmiştir. Sekiz ifade bakımından ise yine çalışmanın hedeflediği yönde olumlu değişiklikler gözlenmiş ise de bu değişiklikler istatistiksel olarak anlamlı bulunmamıştır. Bir ifade bakımından ise olumlu veya olumsuz yönde herhangi bir değişiklik olmamıştır.

\section{TARTIŞMA (DISCUSSION)}

Uygulama sonunda öğretmenlerin kendilerine sunulan tartışmalı konularla ilgili görüşlerinin 8. ifade dışında olumlu şekilde değiştiği gözlemlenmiştir. Öğretmenler daha yüksek ortalamalarla tartışmalı konuların sınıflara getirilmesini, tartışmalı konular öğretimine ihtiyaç duyulduğunu, öğrencilerin ilgisini çekebileceğini, öğrencilerle çatışmalarla baş etmeyi öğretmenin önemli olduğunu, karar vermeden önce bütün görüşlerin etraflıca incelenmesi gerektiğini, kendilerini bu konuda daha yeterli gördüklerini, tartışmalı konuları öğretmek için sistemli bir hazırlığa gerek duyulduğunu, eğitim sisteminin tartışmalı konulara daha destekleyici şekilde yapılandırılması gerektiğini ve sadece olguları öğretip tartışmalardan kaçınmanın doğru olmadığını bildirmişlerdir.

Öğrencilerde kafa karışıklığına yol açabileceği şeklindeki yargı ise hem doğru hem de bu eylem araştırmasının uygulayıcısı açısından dikkate değer bir veridir. Doğrudur, çünkü tartışmalı konular öğretiminin amaçlarından birisi de öğrencinin kafasında soru işaretleri oluşturmak ve onu araştırmaya yöneltmektedir (Stradling, Noctor ve Baines,1984 Akt: Berg, Graffe ve Holden, 2003; Hand ve Levinson, 2012). Tartışmalı konular öğretiminin bu yönünü vurgulamak açısından çalışmanın yetersiz kaldığı anlaşılmakta ve daha sonra yapılacak çalışmalarda bu konunun daha etkili bir şekilde alınması planlanmaktadır. Öğretmenlerin toplumun tartışmalı gördüğü konuları öğretmekten kaçınacaklarını belirtmeleri de çalışmanın amaçları bakımından hem olumlu hem de olumsuz yanları içinde barındırmaktadır. Bu çekinceler, öğretmenlerin tartışmalı konular kavramının önemini kavradıklarını, bu konuların gündelik tartışmalardan farklı, duygusal yapıya hitap eden, değerleri içeren ve kontrolden çıkma riski taşıdığı için dikkatlice ele alınması gereken konular olduğunu anladıklarını göstermesi bakımından olumludur. Ancak her halükarda tartışmalı konuları sınıfta ele almak gerektiği konusunda öğretmeleri tam olarak bilinçlendirememiş olmak çalışma adına bir eksiklik olarak not edilmiştir.

Öte yandan sosyal bilgiler öğretmenlerinin görüşlerinde istatistiksel olarak önemli değişikliklerin olduğu ifadeler de proje açısından son derece önemli kazanımlara işaret etmektedir. Öğretmenler karar verme süreçlerine konuyla ilgili bütün paydaşların görüşlerinin dâhil edilmesi gerektiğini ( $\mathrm{p}=$,027<,05) düşünmektedirler. Ayrıca öğretmenler kendilerini tartışmalı konuların öğretilmesi açısından daha yeterli hissetmektedirler $(\mathrm{p}=, 013<, 05)$ ki bu da çalışmanın ana amacı bakımından başarıya ulaştığını göstermektedir. Ayrıca öğretmenler tartışmalı konular öğretimi için özel bir hazırlık ve yaklaşımın gerekli olduğu konusunda da istatistiksel olarak anlamlı derecede olumlu düşüncelere $(\mathrm{p}=, 034<, 05)$ sahip olmuşlardır. Son olarak konuyla ilgili tartışmaları gündeme getirmeksizin salt olguların öğretimiyle yetinmenin yeterli olamayacağı görüşü de çalışmanın sonunda istatistiksel olarak anlamlı derecede $(\mathrm{p}=, 012<, 05)$ gelişmiştir. 


\section{SONUÇ VE ÖNERILER (RESULT AND RECOMMENDATIONS)}

Sonuç olarak çalışmanın amacına büyük ölçüde ulaştığı düşünülmektedir. Yukarıda ele alındığı gibi bir takım eksiklikler bulunsa da burada oluşan tecrübeye dayanarak araştırmacılar gelecekte daha kapsamlı ve yetkin çalışmalar yapabileceklerdir. Sosyal Bilgiler öğretmenlerine tartışmalı konular öğretiminde kullanabilecekleri önemli öğretim yöntemleri tanıtılmış, tartışmalı konular öğretimindeki muhtemel zorluklar ve bunların nasıl aşılacağına yönelik eğitim verilmiş ve tartışmalı konuların sınıfa nasıl getirilebileceği ve öğrencilerin tartışmaya nasıl hazırlanabileceği konularında ipuçları sağlanmıştır. Bu eğitiminden elde edilen sonuçlar, tartışmalı konular hakkında verilecek bir eğitimden sosyal bilgiler öğretmenlerine son derece yararlı olduğunu göstermektedir. Bu konuda üniversitelerin eğitim fakülteleri tarafından sosyal bilgiler öğretmenlerine hizmet içi eğitimler sağlanmasının faydalı olacağı düşünülmektedir. Bu eğitim il milli eğitim müdürlükleri tarafından da veya milli eğitim üniversite işbirliği ile de gerçekleştirilebilir. Daha ileri bir adım olarak eğitim fakülteleri, özellikle sosyal bilgiler anabilim dalları, bu konuda seçmeli dersler açmayı düşünebilirler. Bu derslerin gelecekteki sosyal bilgiler öğretmenlerinin mesleki formasyonları üzerinde olumlu etkileri olacağı düşünülmektedir.

\section{NOT (NOTICE)}

Bu çalışma, TUBİTAK 4005 Bilim ve Toplum Yenilikçi Eğitim Uygulamaları kapsamındaki 213B744 numaralı DÜŞÜN-TARTIŞ isimli proje sonuçlarına göre uyarlanmıştır.

\section{KAYNAKLAR (REFERENCES)}

- Advisory Group on Citizenship, (1998). Education for citizenship and the teaching of democracy in schools. http: //www.educationengland.org.uk/documents/pdfs/1998-crickreport-citizenship.pdf (25 Ekim 2013).

- Asimeng Boahene, L., (2007). Creating strategies to deal with problems of teaching controversial issues in social studies education in African schools. Intercultural Education, 18 (3), 231-242. doi: 10.1080/14675980701463588.

- Barton, K. and McCully, A., (2007). Teaching contreversial issues...where controversial issues really matter. Teaching History, (127), s.13-19.

- Berg, W., Graffe, L., and Holden, C., (2003). Teaching Controversial Issues: a European Perspective. Londra: Cice.

- Byford, J., Lennon, S., and Russell, W.B., (2009). Teaching Controversial Issues in the Social Studies: A Research Study of High School Teachers. Clearing House: A Journal of Educational Strategies, Issues And Ideas, 82(4), 165-170.

- Clarke, P., (2000). Teaching Controversial Issues: A four-step classroom strategy for clear thinking on controversial issues, Green Teacher, 62, 29-32, 11.

- Fraenkel, J., Wallen, N., and Hyun, H.H., (2012). How to design and evaluate research in education (8th ed.). Boston: McGraw Hill.

- Hand, M. and Levinson, R., (2012). Discussing Controversial Issues in the Classroom. Educational Philosophy \& Theory, 44(6), 614-629.

- Harwood, A.M., Hahn, C.L., and ERIC Clearinghouse for Social Studies/Social Science Education, B.N., (1990). Controversial Issues in the Classroom. ERIC Digest. 
- Johnson, D.W. and Johnson, R.T., (1988). Critical thinking through structured controversy. Educational Leadership 45 (8): 58-64.

- Kuzu, A., (2009). Öğretmen yetiştirme ve mesleki gelişimde eylem araştırması. Uluslararası Sosyal Araştırmalar Dergisi, (2) 6, 425-433

- Pakistan Higher Education Comission, (2012). Teaching Social Studies. http://www.hec.gov.pk/InsideHEC/Divisions/AECA/CurriculumRevisio n/Documents/TeachingSocStudies_Sept13.pdf (25 Ekim 2013).

- Pakistan Higher Education Commission, (2012). Teaching social studies: course guide. Islamabad: Higher Education Commission

- Rossi, J.A., (2006). The dialogue of democracy. Social Studies, $97(3), \quad 112-120$

- Strauss, A.L. and Westlun, J., (2005). Teaching about controversial issues. 2005 Mart'ta EE Capacity Building Workshop'ta Ely Minnesota'da sunuldu.

- http://www.procon.org/sourcefiles/teaching-about-controversialissues.pdf (12 Ekim 2013).

- University of Western Australia, (t.y). Inclusive practices for managing controversial issues. http: / /www.hr.uwa.edu.au/equity/inclusive-campusculture/cultural/tool-kit/?a=697869 (26 Ekim 2013).

- Woolley, R., (2010). Tackling controversial issues in the primary school: facing life' s challenges with your learners. Londra: Routledge.

- Yazıcı, S. ve Seçgin, F., (2010). Tartışmalı konular ve öğretimine ilişkin bir çalışma. Uluslararası Sosyal Araştırmalar Dergisi, 3(12), 488-501. 